\title{
Development of a sensitive RT-PCR method for amplifying and sequencing near full-length HCV genotype 1 RNA from patient samples
}

\author{
Eileen Z Zhang, Doug J Bartels, J Dan Frantz, Sheila Seepersaud, Judith A Lippke, Benjamin Shames, Yi Zhou, \\ Chao Lin, Ann Kwong and Tara L Kieffer ${ }^{*}$
}

\begin{abstract}
Background: Direct-acting antiviral (DAAs) agents for hepatitis $\mathrm{C}$ virus (HCV) span a variety of targets, including proteins encoded by the NS3/4A, NS4B, NS5A, and NS5B genes. Treatment with DAAs has been shown to select variants with sequence changes in the HCV genome encoding amino acids that may confer resistance to the treatment. In order to assess these effects in patients, a Reverse Transcription Polymerase Chain Reaction (RT-PCR) method was developed to sequence these regions of HCV from patient plasma.
\end{abstract}

Methods: A method was developed to amplify and sequence genotype 1 HCV RNA from patient plasma. Optimization of HCV RNA isolation, CDNA synthesis, and nested PCR steps were performed. The optimization of HCV RNA isolation, design of RT-PCR primers, optimization of RT-PCR amplification conditions and reagents, and the evaluation of the RT-PCR method performance is described.

Results: The optimized method is able to successfully, accurately, and reproducibly amplify near full-length genotype 1 HCV RNA containing a wide range of concentrations $\left(10^{3}\right.$ to $\left.10^{8} \mathrm{IU} / \mathrm{mL}\right)$ with a success rate of $97 \%$. The lower limit of detection was determined to be $1000 \mathrm{IU} / \mathrm{mL}$ HCV RNA.

Conclusions: This assay allows viral sequencing of all regions targeted by the most common DAAs currently in development, as well as the possibility to determine linkage between variants conferring resistance to multiple DAAs used in combination therapy.

Keywords: Hepatitis C Virus (HCV), Reverse Transcription Polymerase Chain Reaction (RT-PCR), Genotype, Direct Acting Antiviral Agents (DAA), Lower Limit of Detection (LLOD), Quasispecies, Sequencing, Resistance, NS (Non-structural), NS3/4A, NS4B, NS5A, NS5B

\section{Background}

More than 170 million people (3\% of the world population) are infected with hepatitis $\mathrm{C}$ virus $(\mathrm{HCV})[1]$. Chronic HCV infection is a major cause of liver cirrhosis and hepatocellular carcinoma (HCC), as well as liver failure. Liver failure is one of the most common indications for liver transplantation in the United States $[2,3]$. The recent development of potent, direct-acting antiviral agents (DAAs), used in combination with pegylated-interferon (Peg-IFN) and ribavirin (RBV) has

\footnotetext{
* Correspondence: Tara_Kieffer@vrtx.com

Vertex Pharmaceuticals Incorporated, 130 Waverly Street, Cambridge, MA 02139-4242, USA
}

\section{Biomed Central}

(c) 2013 Zhang et al.; licensee BioMed Central Ltd. This is an Open Access article distributed under the terms of the Creative Commons Attribution License (http://creativecommons.org/licenses/by/2.0), which permits unrestricted use, distribution, and reproduction in any medium, provided the original work is properly cited. significantly improved the sustained virologic response rates compared with Peg-IFN and RBV alone [4,5].

$\mathrm{HCV}$ has high genetic variability across the six major genotypes as well as in different subtypes within each genotype. Genotype 1, the predominant cause of chronic HCV infections in the United States, Europe, and Japan, has more diversity within subtypes $1 \mathrm{a}$ and $1 \mathrm{~b}$ than the entire diversity of HBV and HIV [6]. In an HCV-infected patient, this pre-existing genetic variability provides a pool of variants that can adapt to new selection pressures, such as antiviral treatment. The variants are a natural part of the viral quasispecies, which arise from the error-prone nature of the HCV RNA-dependent RNA polymerase and the high replication rate of the virus [7]. 
In patients who fail treatment with a potent DAA regimen, the elimination of the majority of the DAAsensitive quasispecies can lead to selection and detection of DAA-resistant variants [8].

The nonstructural (NS) HCV proteins NS3, NS4A, NS4B, NS5A, and NS5B are essential for viral replication and are the major targets of DAAs currently in development [9]. Thus, monitoring viral sequence changes across multiple NS regions is beneficial in understanding the potential association between therapeutic resistance and clinical outcome [10].

Various methods for amplification and sequence analysis of specific HCV genomes have been reported, and most of them have focused on individual NS segments or smaller amplicons [11-14]. In 2006, a long reverse transcription polymerase chain reaction (RT-PCR) amplification protocol of a near full-length $\mathrm{HCV}$ genome was developed by Fan, X, Xu, Y, and Di Bisceglie, AM, that amplified a limited number of patient samples [15-17]. While conducting telaprevir (INCIVEK ${ }^{\mathrm{TM}}$, INCIVO $^{\circledR}$ ) clinical trials $[18,19]$, the need arose to develop a method to analyze the $\mathrm{HCV}$ genotype 1 sequence of NS3, NS4A,NS5A, and NS5B from a single genome or the catalytic domain of the NS3.4A protease domain from a large number of patients. The challenge was that samples from patients are extremely variable and existing methods described in the literature required patient-by-patient optimization to efficiently amplify near full-length HCV RNA, particularly in samples with low HCV RNA levels, which were common in patients who were responding to telaprevir and/or VX-222. In this study, we describe the development of an efficient RT-PCR method that was used in telaprevir clinical trials to amplify a nearly full-length $\mathrm{HCV}$ genotype 1 genome from 7800 unique patient samples containing a wide range of $\mathrm{HCV}$ RNA concentrations $\left(10^{3}\right.$ to $\left.10^{8} \mathrm{IU} / \mathrm{mL}\right)$ with a success rate of $97 \%$ [4,5,20-23]. This method enables $\mathrm{HCV}$ genes, targeted by the most common DAAs in clinical trials today, to be efficiently sequenced using clinical samples with low HCV RNA levels and permits the assessment of linkage between multiple amino acid changes in different HCV genes in samples from patients receiving DAA drug combinations.

\section{Results and discussion}

\section{Optimization of HCV RNA extraction}

The use of the 96-well format QIAamp Virus BioRobot 9604 Kit (QIAGEN, Valencia, CA) was optimized to produce high-quality viral RNA from HCV RNA-positive plasma. Several modifications were made, with the primary change involving the replacement of the carrier RNA in the RNA isolation. Comparison of the use of poly A RNA (rA) provided in the QIAGEN kit with transfer RNA (tRNA) (Roche Applied Science, Indianapolis, IN) or ribosomal
RNA (rRNA) (Roche Applied Science, Indianapolis, IN) using plasma samples with a wide range of HCV RNA copy numbers $(10 \sim 18,500 \mathrm{HCV}$ RNA copies/reaction) showed that $60 \mu \mathrm{g}$ of tRNA per column for $660 \mu \mathrm{L}$ plasma led to the highest level of sensitivity in the subsequent amplification reaction. In addition, several other minor changes to the standard QIAamp protocol also increased viral RNA purity and quality, which helped the performance of subsequent amplifications including mixing via gentle rocking, instead of pipetting (per the BioRobot 9604 Kit protocol), to minimize shearing of the $9.6 \mathrm{~kb}$ HCV RNA. Also, for optimal recovery of viral RNA, the samples were lysed at $56^{\circ} \mathrm{C}$ and an additional spin step was added following the final wash step to eliminate residual ethanol carry-over.

\section{cDNA synthesis}

Synthesis of cDNA is a critical step in the ability to amplify large PCR products, such as the $9.6 \mathrm{~kb} \mathrm{HCV}$ genome. Optimization of the cDNA synthesis from $\mathrm{HCV}$ RNA involved testing different oligonucleotide primers including random hexamers, oligo d(A) (20 nucleotide), and primers that annealed in the NS5B or 3' untranslated region (UTR). Surprisingly, most of the primers binding in the NS5B or 3'UTR did not allow amplification of full-length viral RNA or lead to very low cDNA yields. In contrast, oligo dA20, which anneals to the highly conserved poly (U) tail at the 3' end of the HCV RNA, did allow for high sensitivity and reproducible amplification of full-length cDNA. We also tested several conditions and concentrations of Reverse Transcriptase enzyme (Superscript ${ }^{\mathrm{TM}}$ III Reverse Transcriptase [Life Technologies Corporation, Carlsbad, CA]) and it was determined that the use of 400 units with a 2.5 hour protocol, containing increasing annealing/elongation temperatures, was preferred.

\section{Amplification of HCV via nested PCR}

To amplify sufficient amounts of the HCV genome for subsequent sequence analysis, PCR primers and conditions were optimized. Using several hundred publicly available genotype $1 \mathrm{HCV}$ sequences (Los Alamos HCV Sequence Database [24]), the regions of highest conservation in the 5' and 3'UTRs were selected for potential primer annealing sites. Subsequent evaluation of primers to the conserved regions showed a diversity of responses in the assay. Many primers resulted in either a poor PCR yield, potentially due to the secondary structure of $\mathrm{HCV}$ RNA in the binding region, or a poorer than expected effectiveness across a spectrum of multiple samples. The highest performing primer annealing sites were at base pair (bp) 242-271 in the 5'UTR and bp 9278-9305 in the NS5B coding region. When various primer lengths were investigated, the use of 28-30 bp oligonucleotide primers led to the highest sensitivity and 
Table 1 List of primers used for the amplification of the HCV coding region

\begin{tabular}{|c|c|c|c|}
\hline RT primer & & Oligo d(A) & $\begin{array}{l}\text { 5'-AAAAAAAAAAAAAAAA } \\
\text { AAAA-3' }\end{array}$ \\
\hline \multirow[t]{4}{*}{$\mathrm{PCR} 1$ primers } & Subtype 1a & GEN1.F1: & $\begin{array}{l}\text { 5'-CAAGACTGCTAGCCGAG } \\
\text { TAGTGTTGGGTCG-3' }\end{array}$ \\
\hline & & GEN1A.R1 & $\begin{array}{l}\text { 5'-CCGGGCAYGAGACACGCT } \\
\text { GTGATAAATG-3' }\end{array}$ \\
\hline & Subtype $1 b$ & GEN1.F1 & $\begin{array}{l}\text { 5'-CAAGACTGCTAGCCGAGTA } \\
\text { GTGTTGGGTCG-3' }\end{array}$ \\
\hline & & GEN1B.R1 & $\begin{array}{l}\text { 5'-TCGGGCACGAGACAVGCTG } \\
\text { TGATATATG-3' }\end{array}$ \\
\hline \multirow[t]{4}{*}{$P C R 2$ primers } & Subtype 1a & GEN1.F2 & $\begin{array}{l}\text { 5'-GTACTGCCTGATAGGGTGCT } \\
\text { TGCGAGTGCC-3' }\end{array}$ \\
\hline & & GEN1A.R2 & $\begin{array}{l}\text { 5'-TCTCCCCCGCTGTAGCCAGC } \\
\text { CGTGAACC-3' }\end{array}$ \\
\hline & Subtype $1 b$ & GEN1.F2 & $\begin{array}{l}\text { 5'-GTACTGCCTGATAGGGTGCT } \\
\text { TGCGAGTGCC-3' }\end{array}$ \\
\hline & & GEN1B.R2 & $\begin{array}{l}5^{\prime}-\mathrm{TCTCCCCCGCTGTARCCAGC} \\
\text { RACGAACC-3' }\end{array}$ \\
\hline
\end{tabular}

amplification across a spectrum of varied samples, by potentially annealing to viral genomes with several nucleotide mismatches from the primer. Also, to increase the ability to amplify across a spectrum of samples from a large number of patients, some degeneracy was added in the least conserved nucleotides in each annealing region. Differences in the primer annealing regions between subtypes $1 \mathrm{a}$ and $1 \mathrm{~b}$ led to the design of subtypespecific primers (Table 1). Conditions with the largest impact on assay performance included the use of a touchdown PCR method (ramping annealing temperatures) for increased specificity, and addition of a second nested PCR reaction to increase the sensitivity of the assay to $1000 \mathrm{IU} / \mathrm{mL}$ of HCV RNA (Figure 1). The combination of a highly processive polymerase (KlenTaq $1^{\mathrm{TM}}$ ) with a proofreading ( $p f u$ ) polymerase, and addition of 1.5 M betaine increased the yield of the $~ 9000$ bp PCR product. Betaine is likely acting through the reduction of the bp composition dependence on DNA strand melting $[25,26]$.

\section{Sensitivity of RT-PCR amplification}

To assess the sensitivity of the method, four genotype 1 HCV RNA-positive plasma samples (two subtypes 1a and two subtypes 1 b) were serially diluted with concentrations of HCV RNA ranging from 11-649,000 IU/mL, and two analysts performed the amplification on different days. The HCV RNA-positive plasma samples were processed through the RT-PCR step and subsequent PCR amplifications were performed in triplicate. Samples with $\mathrm{HCV}$ RNA greater than or equal to $1000 \mathrm{IU} / \mathrm{mL}$ had an amplification success rate of $70 \%$ (100 out of 143 samples) in the first attempt. Samples with HCV RNA below $1000 \mathrm{IU} / \mathrm{mL}$ had a much lower amplification success rate of $1.6 \%$ ( 2 out of 121 samples). Therefore, the lower limit of detection (LLOD) of the RT-PCR amplification method was established to be $\sim 1000 \mathrm{IU} / \mathrm{mL}$. No significant differences in success rates were observed either between subtype 1a and 1b samples or between analysts.

\section{Robustness and success rate of amplification and sequencing}

The performance of the assay was subsequently evaluated on a large, diverse set of plasma samples containing $\mathrm{HCV}$ subtypes la or lb from telaprevir and VX-222 clinical trials, with HCV RNA titers ranging from $100 \mathrm{IU} / \mathrm{mL}$ to greater than $10^{7} \mathrm{IU} / \mathrm{mL}$ (Table 2). We processed 7800 unique patient plasma samples containing subtype 1a (5400) and subtype $1 \mathrm{~b}$ (2400) with HCV RNA at or above the assay limit of detection of $1000 \mathrm{IU} / \mathrm{mL}$ from August 2006 to December 2010. The genetic diversity of both subtypes 1a and $1 \mathrm{~b}$ sample sets was similar to sample sets in the public domain (Los Alamos HCV Sequence Database [24]) as shown in Table 3 (Shannon Entropy [27], BioEdit version 7.0.5.3). The majority ( 97\%) of subtype 1a and subtype 1b samples were successfully amplified, and usually on the

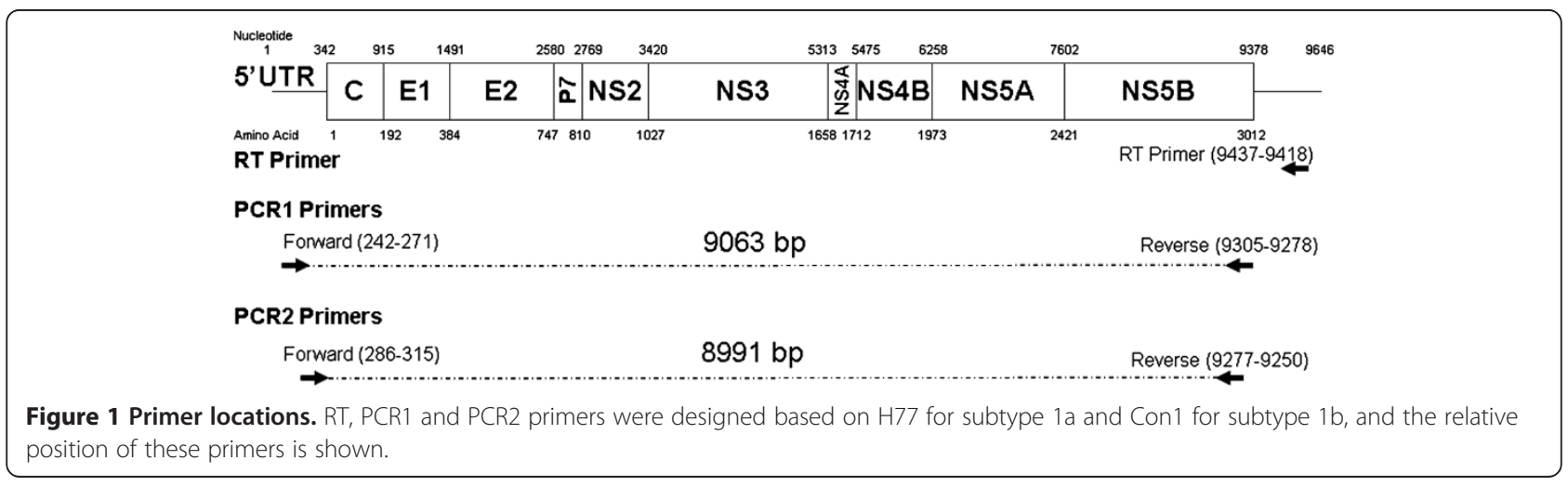


Table 2 Summary of RT-PCR amplification and sequencing success rate of clinical samples from telaprevir and VX-222 clinical trials

\begin{tabular}{lllll}
\hline $\begin{array}{l}\text { HCV RNA } \\
\text { IU/mL) }^{\mathbf{a}}\end{array}$ & $\begin{array}{l}\text { Genotype/ } \\
\text { Subtype }^{\mathbf{b}}\end{array}$ & $\begin{array}{l}\text { Numbers } \\
\text { of clinical } \\
\text { samples }\end{array}$ & $\begin{array}{l}\text { Success rate } \\
\text { of RT-PCR } \\
\text { amplification } \\
\%(\mathbf{n} / \mathbf{N})\end{array}$ & $\begin{array}{l}\text { Success rate } \\
\text { of sequencing } \\
\%(\mathbf{n} / \mathrm{N})\end{array}$ \\
\hline$\geq 1000$ & 1a & 5400 & $97(5238 / 5400)$ & $99.6(5218 / 5238)$ \\
& 1b & 2400 & $97(2328 / 2400)$ & $99.6(2318 / 2328)$ \\
$100-1000$ & $1 a$ & 152 & $48(73 / 152)$ & $98.6(73 / 73)$ \\
& 1b & 107 & $40(43 / 107)$ & $100.0(43 / 43)$ \\
\hline
\end{tabular}

aHCV RNA was assessed using the Roche TaqMan HCV RNA assay (Version 2.0). ${ }^{\mathrm{b}}$ Genotype and subtype was defined using $5^{\prime} \mathrm{NC}$ assay (Trugene) or Versant HCV genotype assay (LiPA) 2.0.

first attempt. For the remaining 3\% of samples that failed to amplify, no correlation with HCV RNA level was observed. The failure of the assay was likely due to high sequence diversity in one or more of the primer binding regions, caused by either the natural high variability in genotype 1 samples, or mis-genotyping of the samples. Testing of samples below the $1000 \mathrm{IU} / \mathrm{mL}$ assay limit of detection, including samples as low as $100 \mathrm{IU} / \mathrm{mL}$, led to a lower success rate $(48 \%$ and $40 \%$ for subtypes $1 \mathrm{a}$ and $1 \mathrm{~b}$, respectively), and were not pursued further. Among the amplified samples, nearly $99 \%$ of the samples were successfully sequenced with a small set of standardized sequencing oligonucleotides, and the sequence information was consistent across replicates. The remaining $1 \%$ of samples for which sequence was not available had the highest sequence diversity in the areas of interest, leading to poor annealing for the sequencing oligonucleotides.

\section{Conclusion}

Despite the high sequence diversity of $\mathrm{HCV}$, successful amplification of a near full-length ( $~ 9 \mathrm{~kb}) \mathrm{HCV}$ genotype 1 genome was completed on $97 \%$ (7566/7800) of patient plasma samples with HCV RNA concentrations greater than or equal to $1000 \mathrm{IU} / \mathrm{mL}$. This method facilitated the examination of sequence changes in the viral population during DAA treatment and aided the development of telaprevir [28]. The ability to amplify and sequence the near full length HCV genome and to look at mutations across multiple DAA targets will be important in the development of multiple DAA-based regimens.

\section{Methods}

Studies included in these analyses were conducted in full compliance with the guidelines of Good Clinical Practice and of the World Medical Assembly Declaration of Helsinki. Prior to study initiation, protocols and informed consent forms were reviewed and approved by institutional review boards at each study site. All patients provided written informed consent before participating in any study-related activity. ClinicalTrials Identifiers for studies included in the manuscript are as follows: NCT00336479, NCT00372385, NCT00420784, NCT00535847, NCT00627926, NCT00983853, NCT00758043, NCT00916474, NCT00528528, NCT00703118, NCT00911963, NCT01080222.

This method is based on the amplification protocol originally described in Kwong et al. [29].

\section{HCV RNA extraction}

Viral RNA was extracted from plasma in a 96-well format according to the manufacturer's instruction with several modifications. Plasma $(220 \sim 660 \mu \mathrm{L}$, the volume was adjusted based on viral load, i.e., $220 \mu \mathrm{L}$ for HCV RNA greater than or equal to $50,000 \mathrm{IU} / \mathrm{mL}$, while $660 \mu \mathrm{L}$ for HCV RNA less than 50,000 IU/mL) was mixed with QIAGEN Protease K $(40 \sim 120 \mu \mathrm{L})$ and QIAamp AL buffer $(240 \sim 720 \mu \mathrm{L})$ supplemented with $20 \sim 60 \mu \mathrm{g}$ of carrier RNA (tRNA) per column. The mixture was incubated for $15 \mathrm{~min}$ at $56^{\circ} \mathrm{C}$, and absolute ethanol $(293 \sim 875 \mu \mathrm{L})$ was added to each well and mixed well. The mixture was loaded into QIAamp column and passed through the column by suction with a peristaltic micropump (IPS-16; Ismatec, Zurich, Switzerland). Subsequently, the column was washed with AW1 buffer $(1000 \mu \mathrm{L})$ and AW2 buffer $(1000 \mu \mathrm{L})$ (provided in QIAGEN kit), respectively, by applying vacuum. A second wash with AW2 buffer (1000 $\mu \mathrm{L}$ ) was spun at $6000 \times \mathrm{g}$ for $10 \mathrm{~min}$ and an additional spin at $6000 \times \mathrm{g}$ for $15 \mathrm{~min}$ was applied to remove residual ethanol. $40 \mu \mathrm{L}$ of RNA storage solution (Ambion) was

Table 3 Comparison of HCV NS3(4A) region of Los Alamos and vertex sequences

\begin{tabular}{|c|c|c|c|c|c|}
\hline Subtype & Sequence domain & Number of sequences ${ }^{\circ}$ & $\begin{array}{l}\text { Length of alignment } \\
\text { (base pair) }\end{array}$ & $\begin{array}{c}\text { Mean Shannon } \\
\text { entropy }\end{array}$ & $\begin{array}{l}\text { Average pairwise difference } \\
\text { (Standard deviation) }\end{array}$ \\
\hline \multirow[t]{2}{*}{$1 \mathrm{a}$} & Los Alamos Sequences & 695 & 2067 & 0.132014 & $7.5 \%( \pm 1.9 \%)$ \\
\hline & Vertex Sequences & $2111^{*}$ & 2085 & 0.175243 & $9.1 \%( \pm 4.6 \%)$ \\
\hline \multirow[t]{2}{*}{$1 b$} & Los Alamos Sequences & 561 & 2067 & 0.158275 & $9.3 \%( \pm 1.5 \%)$ \\
\hline & Vertex Sequences & $1335+$ & 2085 & 0.202466 & $10.6 \%( \pm 3.4 \%)$ \\
\hline
\end{tabular}

- Sequences of HCV NS3(4A) region.

* GenBank accession numbers: KC125008-KC127118.

† GenBank accession numbers: KC123434-KC124768. 
loaded into each column and incubated at room temperature for $5 \mathrm{~min}$. The RNA was eluted by centrifugation at $6000 \times \mathrm{g}$ for $10 \mathrm{~min}$. The elution was repeated once to increase the yield. A total of $80 \mu \mathrm{L}$ viral RNA was isolated from 220 to $660 \mu \mathrm{L}$ of plasma.

\section{CDNA synthesis}

A complementary DNA (cDNA) fragment was synthesized from HCV RNA that was diluted (1:2 or 1:4, the dilution factor was based on viral load, i.e., 1:2 and 1:4 for HCV RNA less than 50,000 IU/mL, while 1:4 for HCV RNA greater than or equal to $50,000 \mathrm{IU} / \mathrm{mL}$ ) into a total RT reaction volume of $20 \mu \mathrm{L}$ composed of 2.5 $\mu \mathrm{M}$ of an oligo-dA20 primer (Table 1), 400 units of Superscript $^{\mathrm{TM}}$ III Reverse Transcriptase (Life Technologies Corporation, Carlsbad, CA), 40 units of RNAseOUT (Life Technologies Corporation, Carlsbad, CA), PC2 reaction buffer (50 mM Tris- $\mathrm{HCl} \mathrm{pH} 9.1,16 \mathrm{mM}$ ammonium sulfate, $3.5 \mathrm{mM}$ magnesium chloride, and $150 \mu \mathrm{g} / \mathrm{mL}$ BSA) (AB Peptides, St. Louis, MO), $500 \mu \mathrm{M}$ dNTPs (Clontech, Mountain View, CA), and 5 mM DTT (Life Technologies Corporation, Carlsbad, CA). The RNA was denatured at $65^{\circ} \mathrm{C}$ for $5 \mathrm{~min}$, followed by ramping extension temperatures at $25^{\circ} \mathrm{C}$ for $10 \mathrm{~min}, 42^{\circ} \mathrm{C}$ for $60 \mathrm{~min}, 50^{\circ} \mathrm{C}$ for $30 \mathrm{~min}$, $55^{\circ} \mathrm{C}$ for $30 \mathrm{~min}$, and $70^{\circ} \mathrm{C}$ for $15 \mathrm{~min}$.

\section{Amplification of $\mathrm{HCV}$ via nested PCR}

The cDNA from the RT reaction was diluted 1:1 into a $40 \mu \mathrm{L}$ PCR1 reaction mixture, containing PC2 reaction buffer (AB Peptides, St. Louis, MO), $200 \mu \mathrm{M}$ dNTPs (Clontech, Mountain View, CA), 1.5 M betaine (Sigma Aldrich, St. Louis, MO), 2.56 units Klentaq DNA polymerase (AB Peptides, St. Louis, MO), 1.28 units pfu DNA polymerase (Stratagene, La Jolla, CA), and $400 \mu \mathrm{M}$ each subtype-specific primer (Table 1 ). The PCR1 reaction was incubated at $94^{\circ} \mathrm{C}$ for $2 \mathrm{~min}$, followed by 30 cycles at $94^{\circ} \mathrm{C}$ for $15 \mathrm{sec}, 68^{\circ} \mathrm{C}-0.5^{\circ} \mathrm{C} /$ cycle ("touchdown" PCR) for $20 \mathrm{sec}$, followed by an incubation at $68^{\circ} \mathrm{C}$ for $12 \mathrm{~min}$. The completed PCR1 reaction was diluted 1:10 into a second PCR mixture (PCR2, $50 \mu \mathrm{L}$ ). The reaction composition and PCR cycling parameters were identical to the PCR1 reaction, with the following changes; 3.2 units Klentaq DNA polymerase, 1.6 units of $P f u$ DNA polymerase, and nested subtype-specific primers were utilized (Table 1).

\section{Preparation of sample for sequencing}

The PCR2 product (8991 bp) was analyzed and verified by agarose gel electrophoresis, and purified using the QIAquick 96 PCR Purification kit (QIAGEN, Valencia, CA). The purified PCR2 product was subsequently quantified using a NanoDrop 8000 Spectrophotometer (Thermo Scientific, Hudson, NH) prior to sequence analysis.

\section{Abbreviations}

bp: Base pair; CDNA: Complementary DNA; DAA: Direct-acting antiviral; dNTP: Deoxyribonucleotide triphosphate; DTT: Dithiothreitol; LLOD: Lower limit of detection; HCC: Hepatocellular carcinoma; HCV: Hepatitis C virus; IU/ mL: International units per milliliter; NS: Nonstructural; RBV: Ribavirin; RTPCR: Reverse-transcriptase polymerase chain reaction; tRNA: Transfer RNA; UTR: Untranslated region.

\section{Competing interests}

Authors are current or former employees of Vertex Pharmaceuticals Incorporated and may own stock or stock options in that company.

\section{Authors' contributions}

TLK, DJB, JDF, JL, SS, BS participated in the design, development and performance of the assay, as well as the sequence alignment and analyses. $A K$ and $C L$ helped with the design of the assay. $Y Z$ and EZZ participated in the optimization, modification, and finalization of the assay. EZZ, DJB, and TLK drafted the manuscript. All authors read and approved the final manuscript.

\section{Authors' information}

Benjamin Shames and Ann Kwong were employees of Vertex Pharmaceuticals Incorporated at time of study.

\section{Acknowledgments}

We thank the study coordinators, nurses, physicians, and patients involved in the clinical trials and Ann Tigges for assistance in generating Shannon Entropy data. We thank Elizabeth Dorn, PhD, Kristin Stephan, PhD, and Erika D. Reynoso, PhD, current employees of Vertex Pharmaceuticals Incorporated, who may own stock or stock options in that company, for editorial support and coordination.

Received: 19 September 2012 Accepted: 7 February 2013 Published: 12 February 2013

\section{References}

1. Butt AA: Hepatitis $C$ virus infection: the new global epidemic. Expert Rev Anti Infect Ther 2005, 3:241-249.

2. Kim WR: The burden of hepatitis C in the United States. Hepatology 2002, 36:S30-\$34.

3. Lavanchy D: The global burden of hepatitis C. Liver Int 2009, 29(Suppl 1):74-81.

4. Jacobson IM, McHutchison JG, Dusheiko G, Di Bisceglie AM, Reddy KR, Bzowej NH, Marcellin P, Muir AJ, Ferenci P, Flisiak R, George J, Rizzetto M, Shouval D, Sola R, Terg RA, Yoshida EM, Adda N, Bengtsson L, Sankoh AJ, Kieffer TL, George S, Kauffman RS, Zeuzem S: Telaprevir for previously untreated chronic hepatitis C virus infection. N Engl J Med 2011, 364:2405-2416.

5. Zeuzem S, Andreone P, Pol S, Lawitz E, Diago M, Roberts S, Focaccia R, Younossi Z, Foster GR, Horban A, Ferenci P, Nevens F, Mullhaupt B, Pockros P, Terg R, Shouval D, van Hoek B, Weiland O, Van Heeswijk R, De Meyer S, Luo D, Boogaerts G, Polo R, Picchio G, Beumont M: Telaprevir for retreatment of HCV infection. N Engl J Med 2011, 364:2417-2428.

6. Ray SC, Thomas DL: Hepatitis C. In Mandell, Douglas, and Bennett's Principles and Practice of Infectious Diseases. 7th edition. Edited by Mandell G, Bennett JE, Dolin R. Amsterdam: Elsevier; 2009:2157-2187.

7. Simmonds P: Genetic diversity and evolution of hepatitis $C$ virus -15 years on. J Gen Virol 2004, 85:3173-3188.

8. Adiwijaya BS, Hare B, Caron PR, Randle JC, Neumann AU, Reesink HW, Zeuzem S, Herrmann E: Rapid decrease of wild-type hepatitis $C$ virus on telaprevir treatment. Antivir Ther 2009, 14:591-595.

9. Kwong AD, Najera I, Bechtel J, Bowden S, Fitzgibbon J, Harrington P, Kempf D, Kieffer TL, Koletzki D, Kukolj G, Lim S, Pilot-Matias T, Lin K, Mani N, Mo H, O'Rear J, Otto M, Parkin N, Pawlotsky JM, Petropoulos C, Picchio G, Ralston R, Reeves JD, Schooley RT, Seiwert S, Standring D, Stuyver L, Sullivan J, Miller $V$ : Sequence and phenotypic analysis for resistance monitoring in hepatitis $C$ virus drug development: recommendations from the $\mathrm{HCV}$ DRAG. Gastroenterology 2011, 140:755-760.

10. Welzel TM, Zeuzem S: Mixing and matching drugs: what makes sense? Clin Liver Dis 2011, 15:657-664. 
11. Aizaki H, Aoki Y, Harada T, Ishii K, Suzuki T, Nagamori S, Toda G, Matsuura Y, Miyamura T: Full-length complementary DNA of hepatitis $C$ virus genome from an infectious blood sample. Hepatology 1998, 27:621-627.

12. Liu Z, Netski DM, Mao Q, Laeyendecker O, Ticehurst JR, Wang XH, Thomas $\mathrm{DL}$, Ray SC: Accurate representation of the hepatitis $\mathrm{C}$ virus quasispecies in 5.2-kilobase amplicons. J Clin Microbiol 2004, 42:4223-4229.

13. Lu L, Nakano T, Smallwood GA, Heffron TG, Robertson BH, Hagedorn CH: A refined long RT-PCR technique to amplify complete viral RNA genome sequences from clinical samples: application to a novel hepatitis $C$ virus variant of genotype 6. J Virol Methods 2005, 126:139-148.

14. Tellier R, Bukh J, Emerson SU, Miller RH, Purcell RH: Long PCR and its application to hepatitis viruses: amplification of hepatitis A, hepatitis $B$, and hepatitis C virus genomes. J Clin Microbiol 1996, 34:3085-3091.

15. Fan $X, X u$ Y, Di Bisceglie AM: Efficient amplification and cloning of near full-length hepatitis $C$ virus genome from clinical samples. Biochem Biophys Res Comm 2006, 346:1163-1172.

16. $\mathrm{Xu} Z$ Z, Fan $X, X u$ Y, Di Bisceglie AM: Comparative analysis of nearly fulllength hepatitis $C$ virus quasispecies from patients experiencing viral breakthrough during antiviral therapy: clustered mutations in three functional genes, E2, NS2, and NS5a. J Virol 2008, 82:9417-9424.

17. Zhou D, Fan X, Tan D, Xu Y, Tavis JE, Di Bisceglie AM: Separation of near full-length hepatitis $C$ virus quasispecies variants from a complex population. J Virol Methods 2007, 141:220-224.

18. INCIVEK' ${ }^{\mathrm{TM}}$ : US perscribing information. Cambridge, MA: Vertex Pharmaceuticals Incorporated; 2012.

19. INCIVO ${ }^{\circledR}$ : EU Summary of Product Characteristics. Beerse, Belgium: Janssen Pharmaceuticals; 2012.

20. Hézode C, Forestier N, Dusheiko G, Ferenci P, Pol S, Goeser T, Bronowicki JP, Bourliere M, Gharakhanian S, Bengtsson L, McNair L, George S, Kieffer T, Kwong A, Kauffman RS, Alam J, Pawlotsky JM, Zeuzem S: Telaprevir and peginterferon with or without ribavirin for chronic HCV infection. N Engl J Med 2009, 360:1839-1850.

21. McHutchison JG, Everson GT, Gordon SC, Jacobson IM, Sulkowski M, Kauffman R, McNair L, Alam J, Muir AJ: Telaprevir with peginterferon and ribavirin for chronic HCV genotype 1 infection. N Engl J Med 2009, 360:1827-1838. Erratum: N Engl J Med. 2009, 361:1516.

22. McHutchison JG, Manns MP, Muir AJ, Terrault NA, Jacobson IM, Afdhal NH, Heathcote EJ, Zeuzem S, Reesink HW, Garg J, Bsharat M, George S, Kauffman RS, Adda N, Di Bisceglie AM: Telaprevir for previously treated chronic HCV infection. N Engl J Med 2010, 362:1292-1303. Erratum: N Engl J Med. 2010, 362:1647.

23. Sherman KE, Flamm SL, Afdhal NH, Nelson DR, Sulkowski MS, Everson GT, Fried MW, Adler M, Reesink HW, Martin M, Sankoh AJ, Adda N, Kauffman RS, George $\mathrm{S}$, Wright Cl, Poordad F: Response-guided telaprevir combination treatment for hepatitis C virus infection. N Engl J Med 2011, 365:1014-1024. Erratum: N Engl J Med. 2011, 365:1551.

24. Kuiken C, Yusim K, Boykin L, Richardson R: The Los Alamos HCV sequence database. Bioinformatics 2005, 21(3):379-384.

25. Henke W, Herdel K, Jung K, Schnorr D, Loening SA: Betaine improves the PCR amplification of GC-rich DNA sequences. Nucleic Acids Res 1997, 25:3957-3958.

26. Rees WA, Yager TD, Korte J, von Hippel PH: Betaine can eliminate the base pair composition dependence of DNA melting. Biochemistry 1993, 32:137-144.

27. Shannon Claude E: A Mathematical Theory of Communication. Bell Syst Tech J 1948, 27(3):379-423.

28. Kieffer TL, De Meyer S, Bartels DJ, Sullivan JC, Zhang EZ, Tigges A, Dierynck I, Spanks J, Dorrian J, Jiang M, Adiwijaya B, Ghys A, Beumont M, Kauffman RS, Adda N, Jacobson IM, Sherman KE, Zeuzem S, Kwong AD, Picchio G: Hepatitis $C$ viral evolution in genotype 1 treatment-naive and treatmentexperienced patients receiving telaprevir-based therapy in clinical trials. PLoS One 2012, 7:e34372.

29. Kwong AD, Frantz JD, Bartels DJ, Lin C, Shames B, Seepersaud S, Lippke JA, Kieffer TL, Zhou Y, Zhang EZ, Sullivan JC, inventors; Vertex Pharmaceuticals Incorporated, assignee: Methods for amplifying hepatitis C virus nucleic acids. 2010. US patent WO/20120/090857 2010.

\section{Submit your next manuscript to BioMed Central and take full advantage of:}

- Convenient online submission

- Thorough peer review

- No space constraints or color figure charges

- Immediate publication on acceptance

- Inclusion in PubMed, CAS, Scopus and Google Scholar

- Research which is freely available for redistribution

Submit your manuscript at www.biomedcentral.com/submit
C Biomed Central 